\title{
Characterization of $\mathrm{CD}^{+} \mathrm{CD}^{+}{ }^{+} \mathrm{B} 2$ Lymphocytes in the Allergic Airways of BALB/c Mice in Response to the Inhalation of Aspergillus fumigatus Conidia $^{\S}$
}

\author{
Sumit Ghosh*, Scott A. Hoselton and Jane M. Schuh \\ Department of Veterinary and Microbiological Sciences, North Dakota State University, Fargo, ND 58108, USA
}

\begin{abstract}
Fungal sensitization in patients with asthma often indicates an unusual disease course in which traditional asthma treatments have little effect and in which morbidity is particularly severe. Airway hyperresponsiveness (AHR), inflammatory infiltrates, smooth muscle hyperplasia, and irreversible fibrotic remodeling of the bronchial architecture are features of allergic fungal asthma. The systemic production of IgE has long been associated with the immunopathogenesis of allergic asthma; however, the role of B lymphocytes and their products in the response to fungal allergens remains unclear. In the present study, we hypothesize that B lymphocytes are recruited to the allergic lung to impact the allergic response. Using a murine fungal aeroallergen model to mimic the human syndrome, we characterized the $\mathrm{B}$ cell population in the lung after fungal challenge and found that $\mathrm{CD} 19^{+} \mathrm{CD} 23^{+} \mathrm{B} 2$ lymphocyte numbers are increased in the allergic lung in a dynamic process. $\operatorname{IgA}, \operatorname{IgG}_{2 \mathrm{a}}$, and $\mathrm{IgE}$ were prominent in the serum and bronchoalveolar lavage fluid of allergic animals. It was evident that a tissue-centric production of these antibodies was possible. IgA-, IgG-, and IgEproducing cells from the allergic lung were identified by flow cytometry and immunohistochemistry. This study shows for the first time that $\mathrm{CD} 19^{+} \mathrm{CD} 23^{+} \mathrm{B} 2$ lymphocyte numbers change in the lung in a dynamic process after inhalation of fungal conidia and their increase has a significant impact on the Ab production in the pulmonary compartment in the context of fungal allergy.
\end{abstract}

Keywords: Fungal asthma, murine model, Ab production, B lymphocytes.

\section{INTRODUCTION}

Aspergillus fumigatus is a saprophytic mold with an important environmental function in carbon and nitrogen cycling [1]. Its hydrophobic spores are readily dispersed in the environment and, when inhaled, are small enough to navigate the airways of the lung far beyond the barriers of the ciliated epithelium [2]. Cellular innate (neutrophil- and macrophagemediated) and adaptive (Th1-mediated) immune responses protect against infection by Aspergillus in a normal lung [3-6], but $A$. fumigatus can induce or exacerbate allergies of the upper and lower airways, and its ubiquitous dissemination in indoor and outdoor environments limits the effectiveness of avoidance strategies. Sensitization to Aspergillus is common in atopic individuals, and A. fumigatus is reported to be responsible for 16-38\% of Aspergillus related illness in humans [7, 8]. In asthmatic individuals, Aspergillus sensitization can herald a particularly difficult to treat disease termed Severe Asthma with Fungal Sensitization (SAFS) [9]. In immunocompromised patients or those with previous lung damage, A. fumigatus may germinate and its growth may cause aspergillomas or invade local blood vessels causing disseminated fungal disease. Invasive disease carries mortality rates ranging from $40-90 \%[1,10]$.

\footnotetext{
*Address correspondence to this author at the Department of Veterinary and Microbiological Sciences, North Dakota State University, Dept 7690, P.O. Box 6050, Fargo, ND 58108-6050, USA; Tel: 701-231-8289; Fax: 701-2319692; E-mail: Sumit.Ghosh@ndsu.edu

${ }^{\S}$ The findings and conclusions in this report are those of the authors and do not necessarily represent the views of North Dakota State University
}

A number of immunoglobulin isotypes are believed to be important in pulmonary response to fungi. At the earliest interface with the lung, IgA from resident B cells is actively pumped across the epithelium to provide innate mucosal protection [11]. We have previously shown that $\operatorname{IgA}$ production is upregulated in the allergic murine bronchoalveolarlavage (BAL) fluid after exposure to inhaled spores [12]. In the immunocompetent, non-atopic host, $\mathrm{IgG}_{2 \mathrm{a}}$ from follicular B2 cells is associated with a Th1 response and has been shown to arrest fungal development, preventing germination of the fungus [13]. In allergic responses, IgE functions in the activation/degranulation of granulocytes. While mast cell degranulation is typically associated with allergic immunopathology, recent work indicates that the degranulation of eosinophils in the lumen may provide protection in response to fungus [14]. In the setting of invasive disease, antibodies to Aspergillus proteins have been noted in patients with aspergillomas and invasive disease $[15,16]$, although the characterization and role of these antibodies is yet not well documented [17].

While a strong phagocytic defense is essential for effective clearance of the inhaled spores and opsonization by Abs may assist this process, it is becoming clear that B cells may play other roles in target tissues where their ability to supply antibody or cytokines at the point of infection or to present antigen to $T$ cells in the tissue may support the development of a productive immune response and/or may contribute to the development of immunopathology [18]. 
Currently, little is known about the spatial and temporal orchestration of the B cell's participation in the allergic response to fungal allergens/pathogens. In this study, we employed a murine model of $A$. fumigatus-induced allergic lung disease that uses the inhalation of unmanipulated, dry spores in order to characterize the $\mathrm{B} 2$ cell population in the pulmonary space, the localization of B cells in the allergic lung, and the production of three major $\mathrm{Ab}$ isotypes in the context of the fungal allergen-sensitized lung. This is a critical step in determining the specific function of B cells, Abs, and B cell-produced cytokines in the response to environmental fungal exposures in the asthmatic patient.

\section{MATERIALS AND METHODS}

\section{Animals}

BALB/c mice were purchased from Jackson Labs (Bar Harbor, ME, USA) and were bred and maintained in a specific pathogen-free facility for the duration of this study. Animals (5-9 weeks old) were fed and given water ad libitum throughout the study and housed on Alpha-dri ${ }^{\mathrm{TM}}$ paper bedding (Shepherd Specialty Papers, Watertown, TN, USA) in micro filter topped cages (Ancare, Bellmore, NY, USA). Prior approval for these studies was obtained from the Institutional Animal Care and Use Committee of North Dakota State University (NDSU).

\section{Antigen Preparation and Conidia Culture}

Soluble A. fumigatus extract was purchased from Greer Laboratories (Lenoir, NC, USA) and fungal culture stock (strain NIH 5233) was purchased from American Type Culture Collection (Manassas, VA, USA). A lyophilized $A$. fumigatus was reconstituted in 5ml PBS and 60- $\mu 1$ aliquots of the suspension were stored at $4{ }^{\circ} \mathrm{C}$ until use. A single aliquot of $A$. fumigatus was grown on Sabouraud dextrose agar (SDA) in a $25-\mathrm{cm}^{2}$ cell culture flask for 8 days at $37^{\circ} \mathrm{C}$. The use of $A$. fumigatus was approved by the NDSU Institutional Biosafety Committee.

\section{Allergen Sensitization and Conidia Inhalation Challenge}

To elicit allergen sensitization, mice were injected subcutaneously (SC) and intraperitoneally (IP) with a total of $10 \mu \mathrm{g}$ of soluble A. fumigatus antigen (Greer Laboratories, Lenoir, NC, USA) dissolved in $0.1 \mathrm{ml}$ PBS and $0.1 \mathrm{ml}$ Imject ${ }^{\circledR}$ Alum (Pierce, Rockford, IL, USA) $[12,19,20]$. Two weeks later, mice were started on a series of five, weekly 20 $\mu \mathrm{g}$ intranasal (IN) inoculations consisting of soluble $A$. fumigatus extract (Greer Laboratories, Lenoir, NC, USA) dissolved in $20 \mu \mathrm{l}$ of normal saline. One week after the final IN inoculation, mice were exposed to $A$. fumigatus by inhalation of mature, airborne conidia, as previously described [19]. Briefly, mice were anesthetized using a cocktail of ketamine $(75 \mathrm{mg} / \mathrm{kg})$ and xylazine $(25 \mathrm{mg} / \mathrm{kg})$, and their noses were placed in the inoculation chamber where they inhaled mature A. fumigatus conidia for $10 \mathrm{~min}$. The sensitization and challenge model is detailed in Fig. (1). At specified time points after allergen challenge, animals were anesthetized with pentobarbital $(150 \mathrm{mg} / \mathrm{kg})$ and tracheostomized for sample collection.

Sample Collection for Serum, Bronchoalveolar Lavage (BAL), and Lung Tissue

Animals were exsanguinated under anesthesia. The blood was centrifuged at $13,000 \mathrm{xg}$ for $10 \mathrm{~min}$ to obtain serum, which was stored at $-20^{\circ} \mathrm{C}$ until use. One milliliter of sterile PBS was used to lavage the bronchoalveolar space. Cells were separated from BAL fluid by centrifugation and added to the single cell suspensions obtained from the lung tissue for use in flow cytometry. BAL fluid was stored at $-20^{\circ} \mathrm{C}$ for later analysis. Right lungs were harvested and used for flow cytometry. Left lungs were fixed in an inflated state with $10 \%$ neutral buffered formalin and embedded in paraffin for histological sectioning. Longitudinal $5-\mu \mathrm{m}$ tissue sections across the coronal plane of the left lung were used for histological analysis.

\section{Quantification of Serum and BAL Fluid for $\operatorname{IgE}_{\text {, }} \mathbf{I g G}_{\mathbf{2 a}}$ and $\operatorname{IgA}$}

Total IgE, $\operatorname{IgG}_{2 \mathrm{a}}$ (BD OptEIA, San Diego, CA, USA), and IgA (Bethyl Laboratories, TX, USA) were quantified via specific ELISA in serum and BAL according to manufacturer's guidelines. Serum samples were diluted in PBS (1:100 for $\operatorname{IgE}, 1: 5000$ for $\operatorname{IgG}_{2 a}$ and 1:500 for $\operatorname{IgA}$ ). The detection limits for the kits were $1.6 \mathrm{ng} / \mathrm{ml}$ for $\mathrm{IgE}, 3.1$ $\mathrm{ng} / \mathrm{ml}$ for $\operatorname{IgG}_{2 \mathrm{a}}$, and $15.625 \mathrm{ng} / \mathrm{ml}$ for $\mathrm{IgA}$.

\section{Flow Cytometry}

Minced right lungs from animals at days 0 (sensitized, but not challenged), 3, 5, 7, 9, 11, and 13 were subjected to collagenase IV (Sigma-Aldrich, St. Louis, MO, USA)

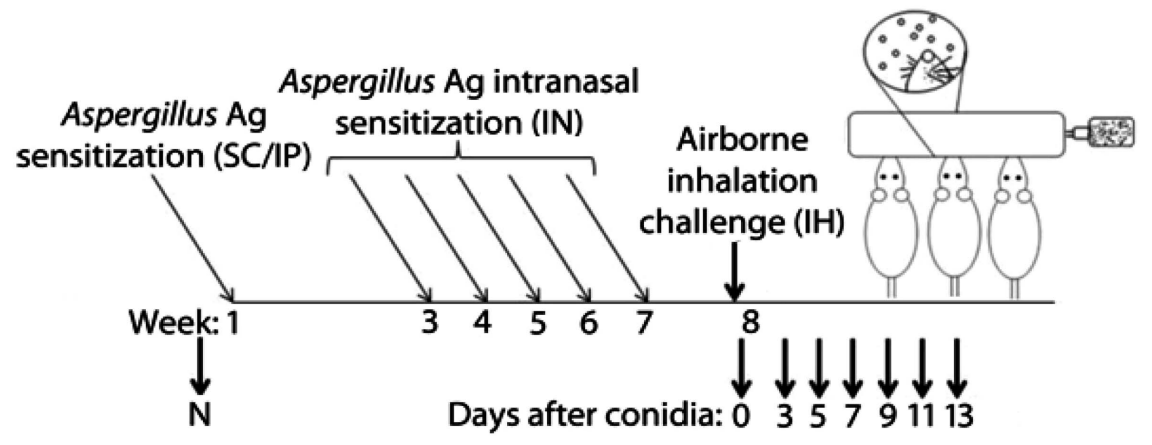

Fig. (1). The Aspergillus fumigatus sensitization and inhalation model. Naïve BALB/c mice (N) received neither sensitization nor conidia challenge. Mice were sensitized with subcutaneous (SC) and intraperitoneal (IP) immunizations of soluble A. fumigatus antigen in alum followed by 5 intranasal (IN) inoculations with soluble antigen in saline. For inhalation (IH) challenge, each of the six treatment groups were exposed to airborne A. fumigatus for $10 \mathrm{~min}$. B lymphocyte numbers along with Ab production were assessed at day 0 (before IH challenge) and at days $3,5,7,9,11$, and 13 after conidia challenge. 
digestion and red blood cell lysis. For collagenase digestion minced lung sections were treated with $0.04 \%$ collagenase IV in DMEM and were incubated at $37^{\circ} \mathrm{C}$ for $1 \mathrm{~h}$. For antibody staining, the cells were suspended in PBS with $1 \%$ BSA (Sigma Aldrich, St. Louis, MO, USA) to a final cell concentration of $1 \times 10^{7}$ cells $/ \mathrm{ml}$. Fc receptors were blocked with anti-mouse CD16/CD32 (1 $\mu \mathrm{g} / 1 \times 10^{6}$ cells) for $10 \mathrm{~min}$ on ice. Samples were surface stained with a cocktail containing $1 \mu \mathrm{g}$ of anti-mouse CD19 FITC and $1 \mu \mathrm{g}$ of antimouse CD23 PE (eBiosciences, San Diego, CA, USA) for 30 min in the dark at $4^{\circ} \mathrm{C}$. For intracellular staining, $1 \times 10^{6}$ cells were fixed and permeabilized using BD Cytofix/Cytoperm ${ }^{\mathrm{TM}}$ kit (BD Biosciences, San Jose, CA, USA). These cells were then stained for intracellular and extracellular immunoglobulins with FITC labeled antibodies for mouse IgE, IgA (eBiosciences, San Diego, USA), and IgG (Invitrogen, Camarillo, CA, USA). Data acquisition was performed using the FACS Caliber flow cytometer (BD Biosciences, San Jose, USA) and analyzed using BD CellQuest Pro software (BD Biosciences, San Jose, USA)/Flow Jo software (Tree Star, Ashland, OR, USA).

Histological Analysis of Inflammation and IgA-, IgG-, and IgE-Producing Cells in the Lung

Hematoxylin and Eosin staining (H\&E) and immunohistochemistry (IHC) was carried out on serial sections of allergic lungs 5 days post conidia inhalation. For IHC, sections affixed to glass slides were submerged in 10$\mathrm{mM}$ citric acid at $\mathrm{pH} 6.0$ and microwaved in a pressure cooker for $10 \mathrm{~min}$ for antigen retrieval. Staining was performed using the HRP-AEC Cell and Tissue Staining Kit (R\&D Systems, Minneapolis, MN, USA) following the manufacturer's recommended protocol. Samples were incubated with $5 \mu \mathrm{g} / \mathrm{ml}$ goat anti-mouse $\operatorname{IgA}$, IgG, or $\operatorname{IgE}$ (Southern Biotech, Birmingham, AL, USA) overnight at $4{ }^{\circ} \mathrm{C}$ in a humidified chamber. Incubation with secondary antibodies was carried out at room temperature for $1 \mathrm{~h}$. Incubation with horseradish peroxidase followed by 3amino-9-ethylcabazole yielded a red precipitate in areas of positive staining. The sections were counterstained, and corresponding areas of H\&E-stained and IHC-stained were photographed using a Zeiss Axio Observer Z1 micrscope (Carl ZeissMicroImaging, Gottingen, Germany).

\section{Statistical Analysis}

Results from sensitized and challenged groups were compared to the sensitized, but unchallenged, control group (day 0). Prism GraphPad software (San Diego, CA, USA) was used to analyze the data using an unpaired Student's two-tailed $t$ test with Welch's correction, $\mathrm{n}=4-5$ lungs per time point. ${ }^{*} \mathrm{p}<0.05$ was reported as statistically significant for these experiments.

\section{RESULTS}

Inhalation of Fungal Conidia Results in a Temporal Increase in Ab Production in Mice Sensitized with A. fumigatus Extract

To determine the temporal production of $\mathrm{Ab}$ isotypes that are known mediators of fungus-induced innate, allergic, and adaptive immune responses, we used specific ELISAs to analyze serum levels of $\operatorname{IgA}, \operatorname{IgG}_{2 \mathrm{a}}$, and $\mathrm{IgE}$ at predetermined time points after A. fumigatus conidia inhalation in sensitized mice. In addition, we assayed levels of these same Abs in pooled BAL fluid samples as an indication of their relative availability in the lung tissue.

We show in this study that $\operatorname{IgA}$ is increased in serum (Fig. 2A) and, even more noticeably, in BAL fluid (Fig. 2B) as early as 3 days after inhalation. Production of $\operatorname{IgG}_{2 \mathrm{a}}$, an isotype prominent in the Th1-mediated cellular response, was not significantly increased in the serum of sensitized mice that had been challenged with conidia as compared to animals that had undergone sensitization only (Fig. 2C). Although statistical significance could not be determined due to the pooling of BAL fluid samples, the levels of $\operatorname{IgG}_{2 a}$ in the lung increased from an undetectable level in the unchallenged, sensitized animals to nearly $5-\mu \mathrm{g} / \mathrm{ml}$ at day 11 after inhalation, suggesting a local production accompanying the inhalation of $A$. fumigatus conidia and/or significant vascular leakage at this time point (Fig. 2D). IgE, the humoral effector of the allergic response, was significantly increased in the serum by day 3 after conidia inhalation (Fig. 2E). Serum IgE levels continued to rise throughout the study, with sensitized and challenged animals measuring a 900-fold increase above control animals at day 13 after conidia inhalation. A similar trend of increased $\mathrm{IgE}$ availability was noted in the BAL fluid, with peak $\operatorname{IgE}$ detection noted at day 11 after conidia inhalation as compared with levels in day-0 control animals (Fig. 2F).

\section{B2 Lymphocytes are Increased in the Sensitized Lungs of BALB/c Mice After Conidia Inhalation}

Flow cytometry was used to track the number of $\mathrm{CD} 19^{+} \mathrm{CD} 23^{+} \mathrm{B} 2$ lymphocytes (conventional B cells) [2123 ] into the allergic lung as a result of the inhalation of $A$. fumigatus spores to determine if $\mathrm{B} 2$ cells were a potential source of isotype-switched $\mathrm{Abs}$ in response to inhaled fungus. Single cell suspensions of pulmonary cells were pooled at each time point and stained with anti-CD19 and anti-CD23 Abs for the detection of B2 cells. The $\mathrm{CD}_{19}{ }^{+} \mathrm{CD} 23^{+} \mathrm{B} 2$ cells were actively increased in the pulmonary tissues after allergen inhalation (Fig. 3A-C). B2 cell numbers increased rapidly and peaked at day 5 after conidia inhalation with an average of 1.7 million B2 cells per lung counted in the sensitized and challenged animals (Fig. 3C).

\section{IgA, IgG, and IgE are Produced in the Lungs of Allergic Mice After Conidia Inhalation}

Cells expressing intracellular and extracellular IgA, IgG, and $\mathrm{IgE}$ were assessed by flow cytometry on pooled single cell suspensions of lung cells. $\operatorname{IgA}^{+}$cells constituted a relatively minor population in the allergic lung. The largest population of $\mathrm{IgA}^{+}$cells was noted at day 5 after allergen challenge, but these accounted for less than $11 \%$ of the Abproducing cells of the lung (Fig. 4A, 4B). $\mathrm{IgG}^{+}$cells made up the largest population of the three isotypes analyzed, with separate peaks at days 5 and 9 after inhalation of conidia (Fig. 4A, C). $\operatorname{IgE}^{+}$cells which are the hallmark of allergic asthma were most notable in the lung 5 days after allergen challenge (Fig. 4A, D). 


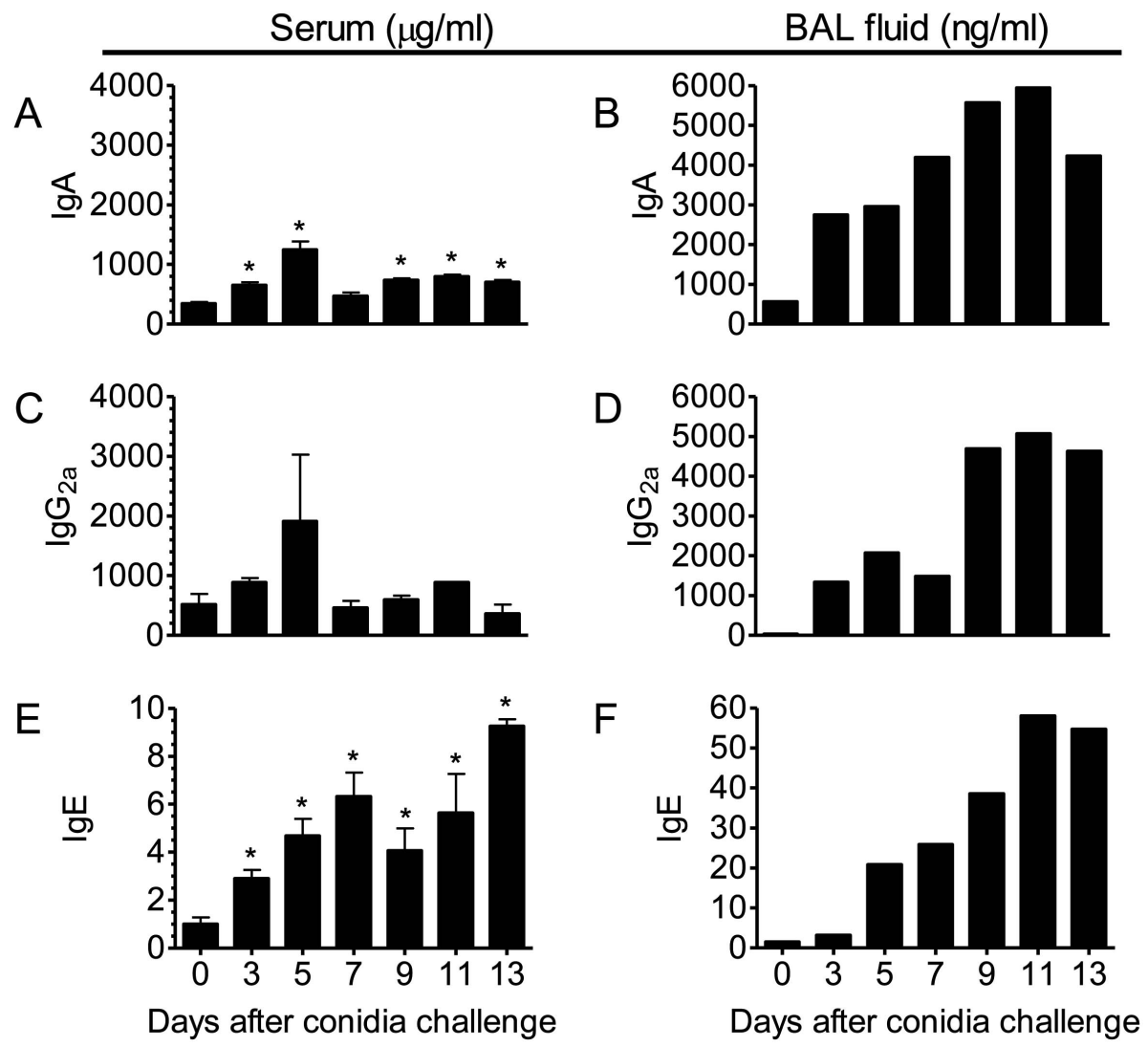

Fig. (2). Effect of the inhalation of $A$. fumigatus on the production of $\operatorname{IgA}, \operatorname{IgG}_{2 a}$, and $\operatorname{IgE}$ isotypes in the serum and $B A L$ fluid of BALB/c mice. Mice were sensitized and exposed to A. fumigatus according to the schedule shown in Fig. (1). Ab isotypes were quantified by specific ELISA in serum and BAL fluid at days 3, 5, 7, 9, 11, and 13 and compared to sensitized mice that were not challenged with inhaled fungal conidia. The resulting data was analyzed using an unpaired, student's two tailed $t$ test with Welch's correction. All values are expressed as the mean \pm S.E.M. $\mathrm{n}=4-5$ mice/group, ${ }^{*} \mathrm{p}<0.05$ was considered statistically significant.

Localization of IgA, IgG, and IgE Positive Cells in the Day 0 (Controls) and Day 5 Lung Tissue Sections of Allergic Mice

Mucosal protection is largely mediated by $\operatorname{IgA}$ that is actively pumped across the mucus membrane. Consistent with the flow data resident $\operatorname{IgA}^{+}$cells were clearly evident around the large airways of allergic animals at day 5 when visualized on tissue sections immunohistochemically stained with anti-IgA antibodies (Fig. 5B). While day 0 BALB/c lungs showed little evidence of IgA production (Fig. 5A). Even though the IgG-producing cells outnumbered IgA- or IgE-producing cells, $\mathrm{IgG}^{+}$cells were rarely noted in the IHCstained tissue sections at day 5 after conidia challenge (Fig. 5D). However, they were present in higher numbers when compared to day 0 controls (Fig. 5C, D). $\operatorname{IgE}^{+}$cells on the other hand were clearly evident in the tissue around large airways and blood vessels (Fig. 5F). These cells may contribute to the local $\mathrm{IgA} / \mathrm{IgG} / \mathrm{IgE}$ production in the $\mathrm{BAL}$ fluid quantified by ELISA.

\section{DISCUSSION}

Aspergillus species are among the most well recognized and best studied fungal pathogens of humans and animals. Exposure to this species can result in a range of disease states from allergic rhinitis to invasive aspergillosis. The innate immune system functions to bar fungal infection and, when that fails, both humoral and cell-mediated adaptive responses function to eliminate fungal pathogens [24]. The contribution of humoral immune responses against fungal pathogens and allergens has been the topic of debate. While it is evident that cell-mediated responses play an important role in fungal clearance [25], the relative importance of serum and BAL antibodies to fungal components has been more difficult to establish $[26,27]$.

B lymphocytes are the tuners of humoral immunity and they develop a specific immune response to A. fumigatus as they have been documented to produce $A$. fumigatus specific $\operatorname{IgA}, \operatorname{IgG}$, and $\operatorname{IgE}$ antibodies [28, 29]. They perform three important functions. In addition to producing antibodies, B cells present antigen to $\mathrm{T}$ cells to indirectly support the allergic phenotype. They can also produce cytokines to directly impact fibrosis and other airway changes [30] suggesting that these cells can play an important role in the development and maintenance of allergic disease.

In this study, we show a temporal change in the B2 lymphocyte population $\left(\mathrm{CD} 19^{+} \mathrm{CD} 23^{+}\right)$in the allergic lung after exposure to conidia, placing these cells in a role to produce antibody isotypes that directly affect the immune response in the lung. Although not the focus of the current study, these cells could have other roles in the development and maintenance of the phenotype that is seen in the allergic lung. 

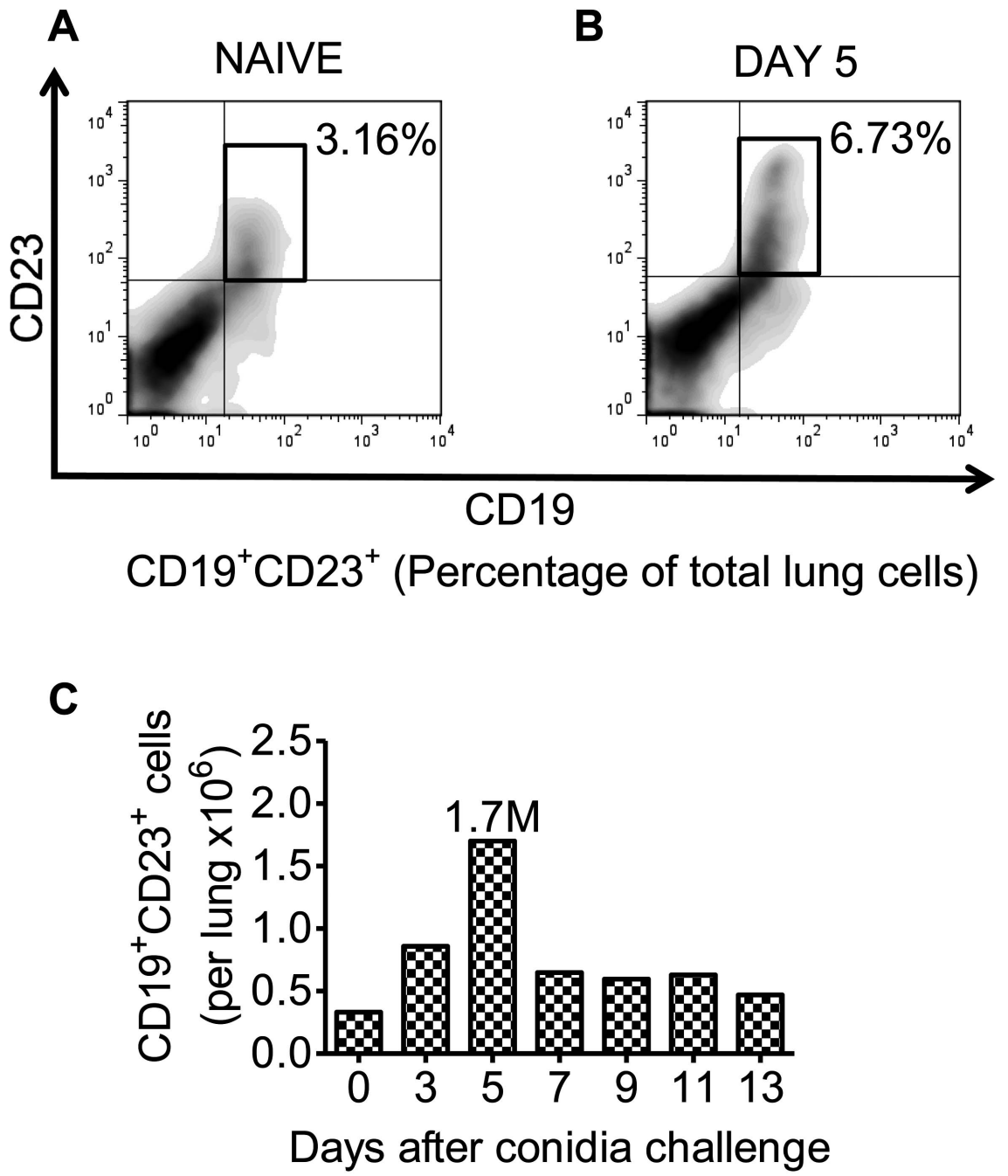

Fig. (3). Effect of $A$. fumigatus conidia inhalation on the $\mathrm{CD}^{+} 9^{+} \mathrm{CD}^{+}{ }^{+} \mathrm{B} 2$ lymphocyte population in the allergic lung. Mice were exposed to A. fumigatus according to the schedule shown in Fig. (1). At days 0, 3, 5, 7, 9, 11, and 13 the lungs were removed and immediately processed into a single cell suspension. Scatter properties were used to identify lymphocytes followed by staining with antiCD19/anti-CD23 antibodies to identify conventional B2 lymphocytes. (A, B) The total percentage of CD19 ${ }^{+} \mathrm{CD} 23^{+} \mathrm{B} 2$ cells in the lungs of day 0 (sensitized, unchallenged with A. fumigatus) and day $5 \mathrm{BALB} / \mathrm{c}$ mice. (C) Total number of CD $19^{+} \mathrm{CD} 23^{+} \mathrm{B} 2$ cells in the lungs of day 0 and A. fumigatus challenged BALB/c mice. $\mathrm{n}=4-5$ mice/ group and all the lung sections were pooled together for antibody staining.

The mucociliary elevator removes the majority of inhaled microbes from the surface of the pulmonary epithelium. B cells support the mucosal immune response by pumping IgA dimers of limited antigenic repertoire across the epithelium onto the luminal surface of the lung [31]. In our study, IgAproducing cells were found to be localized around the large airways. This corresponds with their role as an innate defense immunoglobulin pumped across the columnar epithelium in an attempt to block fungal infection. IgA has been found to be critically important to fungal elimination and a strong immune defense against mold spores [32]. The production of $\operatorname{IgA}$ after exposure to fungal conidia is important because it shows the dynamic activation of this cell type in response to a potential pathogen/particulate.

When the host inhales conidia in large doses or at continuous low levels, fungal sensitization resulting in an aggressive pulmonary allergic response to Aspergillus antigens may arise. The allergic response overlaps the innate cellular component in the sensitized individual resulting in elevated IgE, airway hyperresponsiveness, and peribronchial inflammation. As an example of this collaboration of innate and adaptive immune responses recruitment of both innate response cells and increased IgA production coincident with lymphocyte recruitment to the lung suggests a coordinated strategy for fungal elimination in the lung. Persistent Th2mediated responses give rise to increased peribronchial smooth muscle and collagen deposition which characterizes the airway wall remodeling that often accompanies allergic lung disease [33]. In this study, increased IgA levels corresponded with increased $\operatorname{IgE}$ in serum and BAL. In addition, IgE-producing cells were localized near the large airways of allergic animals. This $\operatorname{IgE}$ production is the hallmark of allergic asthma, as it has the ability to crosslink antigen to elicit mast cell degranulation and the activation of Th2 immune cascade. Even $\operatorname{IgG}_{2 \mathrm{a}}$, which is produced by Th1-associated B cells [34], was elevated throughout the time points and IgG producing cells were present near the large airways indicating its importance in host protection 
A
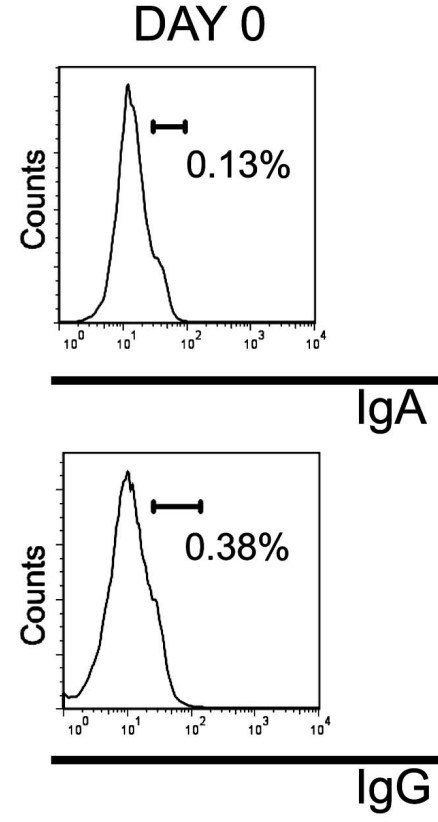

$\lg G$

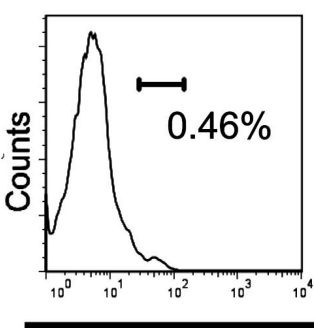

\section{$\lg \mathrm{E}$}

$\mathrm{Ig}^{+}$(Percentage of total lung cells)

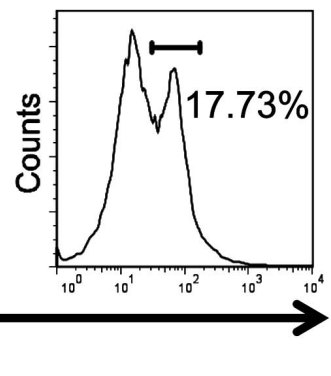

B
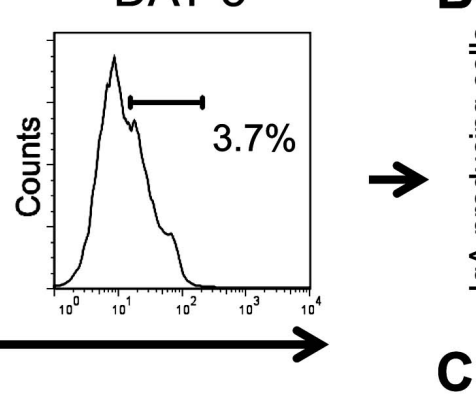

C

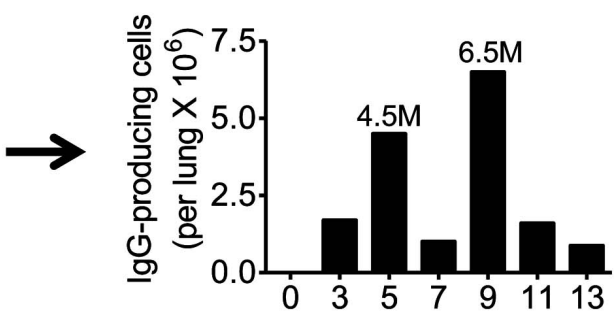

D

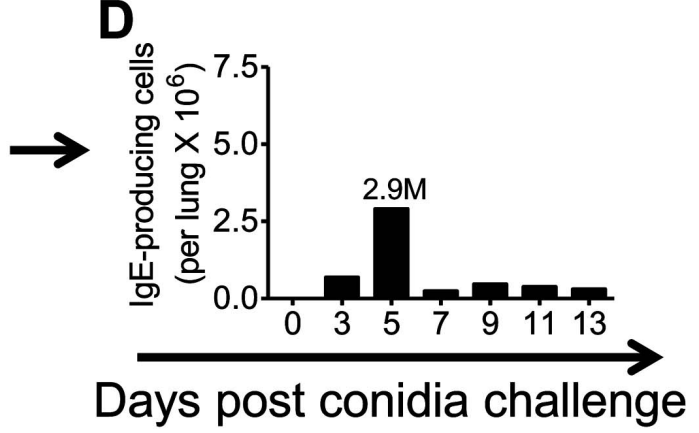

Fig. (4). Effect of $\boldsymbol{A}$. fumigatus conidia inhalation on Ab-producing cells in the allergic murine lung. Mice were exposed to A. fumigatus according to the schedule shown in Fig. (1). At days $0,3,5,7,9,11$, and 13 the lungs were harvested and immediately processed into a single cell suspension. Fluorescent anti-IgE, IgG and IgA antibodies were used to identify antibody producing cells. (A) Histograms representing the total percentage of $\operatorname{Ig}^{+}(\mathrm{IgA} / \mathrm{IgG} / \mathrm{IgE})$ cells in the lungs of day 0 (sensitized, unchallenged with $\mathrm{A}$. fumigatus) and day 5 BALB/c mice. (B) Total number of IgA ${ }^{+}$cells in the lungs of day 0 and day 5 (sensitized and challenged with $A$. fumigatus) BALB/c mice. (C) Total number of $\mathrm{IgG}^{+}$cells in the lungs of day 0 and day 5 (sensitized and challenged with A. fumigatus) BALB/c mice. (D) Total number of $\mathrm{IgE}^{+}$cells in the lungs of day 0 and day $5 \mathrm{BALB} / \mathrm{c}$ mice. $\mathrm{n}=4-5$ mice/ group and all the lung sections were pooled together for antibody staining.

against fungal growth. Nonetheless, the increased numbers of $\mathrm{CD} 19^{+} \mathrm{CD} 23^{+} \mathrm{B} 2$ cells along with increased availability of $\operatorname{IgA}, \operatorname{IgG}_{2 \mathrm{a}}$, and $\operatorname{IgE}$ in the serum and BAL fluid advocates for the investigation of humoral defenses against $A$. fumigatus.

Allergic responses have been suggested as an aberrant immune response mounted against particulates that in many cases are not associated with pathogenic organisms (e.g., pollen, animal dander, and various chemicals). However, two prominent pathogens that have evolved in conjunction with their human hosts-helminthic worms and fungi-both of which are luminal pathogens that are perhaps the driving force behind a luminal immune response that has evolved as the allergic response. Eosinophilia is a hallmark of the allergic airway, and we have previously shown these cells are aptly recruited to the lungs of allergic mice after challenge with inhaled conidia [19, 20, 29]. Contemporary research has revealed that $B$ cells traffic to the lung in disease states [30] and that isotype switching can occur within the lung $[29,35]$.

The lower airways of the normal lung are typically considered to be sterile of bacterial microbes; however, this is not the case for the compact extremely hydrophobic spores of A. fumigatus. These tiny spores can travel well past the ciliated epithelium into small airways of the lung where their density is ideal for deposition. Once lodged in the alveoli, their thermotolerance and permissive substrate use provides the necessary characteristics for an opportunistic pathogen. We have shown previously that inhaled A. fumigatus spores are capable of navigating the airways to lodge in the very small peripheral airways of the mouse [19]. Many studies previously have demonstrated that $\mathrm{T}$ lymphocytes and Th2 cytokines play an important role in the development of allergic lung disease and the downstream events, including inflammation, eosinophilia, mast cell accumulation/activation, and airway remodeling [36-39]. However, very little is known about the B cells which are the tuners of humoral 


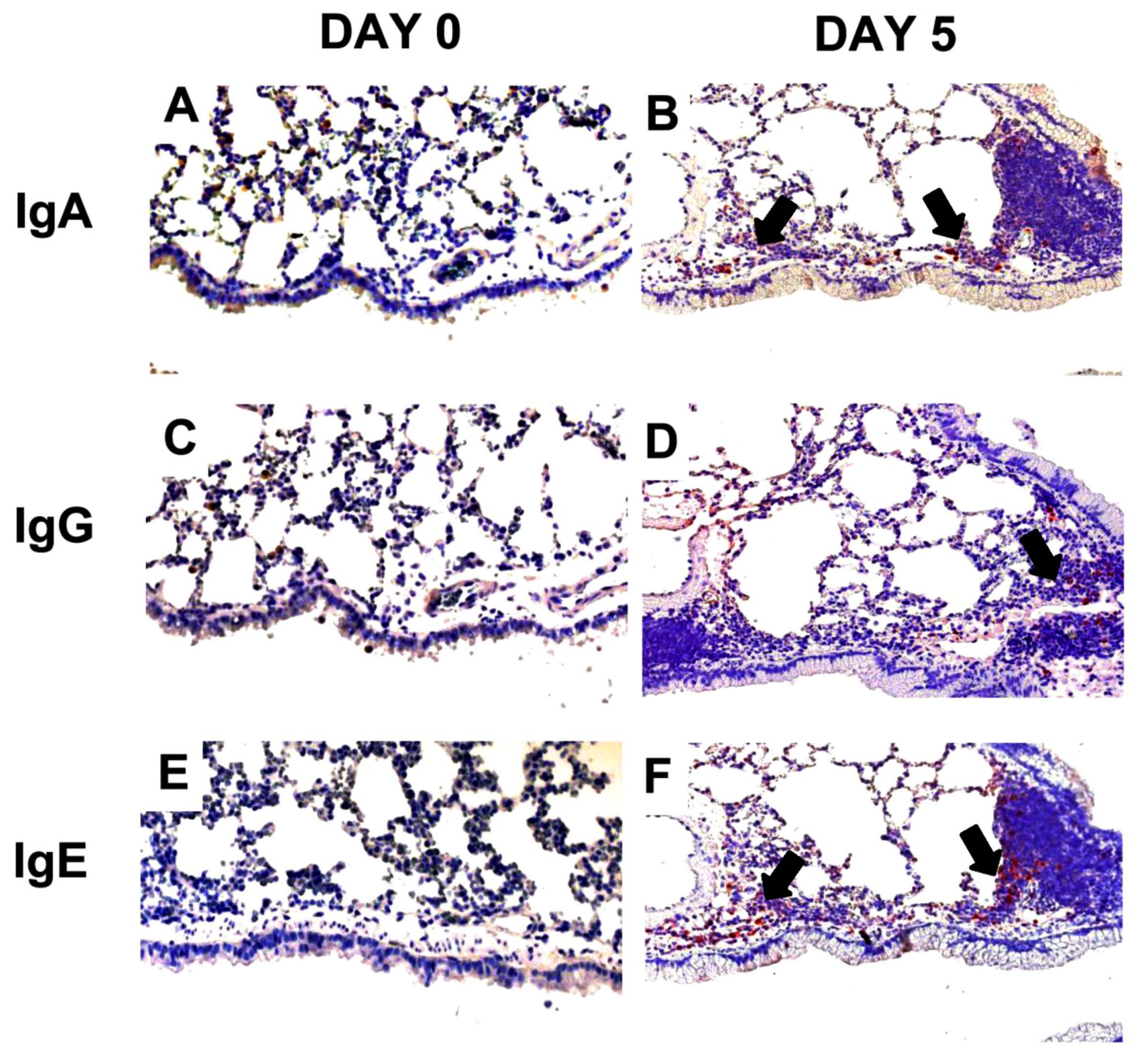

Fig. (5). Effect of inhalation of A. fumigatus conidia on $\operatorname{IgA}, \mathrm{IgG}$, and $\operatorname{IgE}$ antibody producing cells in the allergic mouse lung. Mice were exposed to A. fumigatus according to the schedule shown in figure 1. Immunohistochemical staining was used to identify immunoglobulin producing cells in the lung tissue sections of day 0 (sensitized but not challenged with $A$. fumigatus) and day 5 allergic animals. IgA, IgG and IgE producing cells increased after allergen challenge with maximum numbers at day 5. (A, C, E) Naïve BALB/c lungs had very few cells that localized $\operatorname{Ig}(\operatorname{IgA}, \operatorname{IgG}$, and $\operatorname{IgE})$. (B, D, F) Day 5 BALB/c lungs contained substantial numbers of $\operatorname{IgA}$, IgG, and IgE positive cells localized around the airways (indicated by arrows).

immunity. Previous studies concerning B lymphocytes in allergic disease have concluded that B cells play no role in the development of allergic disease as characterized by eosinophilia and AHR [40, 41]. Other studies have suggested that the contribution of B cells is primary via $\operatorname{IgE}[29,42]$. However, in our study we see that a temporal change in the $\mathrm{CD} 19^{+} \mathrm{CD} 23^{+} \mathrm{B} 2$ cells impacts the antibody phenotype of allergic animals. It would be of interest to study the proliferative status of these B2 lymphocytes in allergic animals. This would help to determine whether extra-lung lymphocytes are recruited to the allergic lung in response to chemotactic signals or the $\mathrm{B} 2$ cells migrating to the allergic lung are proliferating at the site of infection as B2 cells are very much capable of receiving $T$ cell help at the site of infection.

B lymphocytes are active players in host defense as shown by many in vitro studies. While the exact mechanism by which B lymphocytes modulate the allergic response is not known yet, it is possible that these cells may act in synergy with the $\mathrm{T}$ lymphocytes and affect the cytokine milieu of the lungs in addition to antibody production. This is in part supported by the fact that antibody production against inhaled antigens is altered by pulmonary inflammation resulting from diverse pathogenesis [27]. However, further studies are needed to determine the exact role of B lymphocytes in the induction of Th2 cytokines, MHC II expression, and T cell activation

In conclusion, the current report shows for the first time that $A$. fumigatus sensitization and conidia challenge can change the $\mathrm{CD} 19^{+} \mathrm{CD} 23^{+} \mathrm{B} 2$ lymphocyte population in the allergic lung. In addition to this, we suggest a role of $\mathrm{CD} 19^{+} \mathrm{CD} 23^{+} \mathrm{B} 2$ lymphocytes in immunoglobulin secretion in the context of fungal allergy. Taken as a whole, this research supports the increasing body of knowledge that $\mathrm{CD} 19^{+} \mathrm{CD} 23^{+} \mathrm{B} 2$ lymphocytes impact antibody responses in allergic asthma. Further studies analyzing the various 
functions of B cells and their subsets using a knockout model system will shed light on the intricate cellular functions of these cells in allergic asthma and may lead to better treatment for this devastating disease.

\section{CONFLICT OF INTEREST}

The authors confirm that this article has no conflicts of interest.

\section{ACKNOWLEDGEMENTS}

The authors wish to thank Dr. Pawel Borowicz (North Dakota State University) and the Advanced Imaging and Microscopy Laboratory at North Dakota State University for imaging support using the Zeiss Z1 AxioObserver inverted microscope.

Funding source: These studies and the core facility used were funded by grants from the NIH (1R15AI69061: J. Schuh and 2P20RR015566: M. Sibi); and Major Research Instrumentation Program grant from NSF (MRI-R2 grant No.0959512: A. Grazul-Bilska and J. Schuh).

\section{REFERENCES}

[1] Dagenais TR, Keller NP. Pathogenesis of aspergillus fumigatus in invasive aspergillosis. Clin Microbiol Rev 2009; 22: 447-65.

[2] Latge JP. Aspergillus fumigatus and aspergillosis. Clin Microbiol Rev 1999; 12: 310-50.

[3] Beck O, Topp MS, Koehl U, et al. Generation of highly purified and functionally active human TH1 cells against Aspergillus fumigatus. Blood 2006; 107: 2562-9.

[4] Grazziutti ML, Rex JH, Cowart RE, Anaissie EJ, Ford A, Savary CA. Aspergillus fumigatus conidia induce a Th1-type cytokine response. J Infect Dis 1997; 176: 1579-83.

[5] Traynor TR, Huffnagle GB. Role of chemokines in fungal infections. Med Mycol 2001; 39: 41-50.

[6] Murdock BJ, Shreiner AB, McDonald RA, et al. Coevolution of $\mathrm{TH} 1$, TH2, and TH17 responses during repeated pulmonary exposure to Aspergillus fumigatus conidia. Infect Immun 2011; 79: 125-35.

[7] Maurya V, Gugnani HC, Sarma PU, Madan T, Shah A. Sensitization to Aspergillus antigens and occurrence of allergic bronchopulmonary aspergillosis in patients with asthma. Chest 2005; 127: 1252-9.

[8] Schwartz HJ, Citron KM, Chester EH, et al. A comparison of the prevalence of sensitization to Aspergillus antigens among asthmatics in Cleveland and London. J Allergy Clin Immunol 1978; 62: 9-14.

[9] Agarwal R. Allergic bronchopulmonary aspergillosis. Chest 2009; 135: 805-26.

[10] Lin SJ, Schranz J, Teutsch SM. Aspergillosis case-fatality rate: systematic review of the literature. Clin Infect Dis 2001; 32: 35866.

[11] Lorenz RG, McCracken VJ, Elson CO. Animal models of intestinal inflammation: ineffective communication between coalition members. Springer Semin Immunopathol 2005; 27: 233-47.

[12] Samarasinghe AE, Hoselton SA, Schuh JM. The absence of VPAC2 leads to aberrant antibody production in Aspergillus fumigatus sensitized and challenged mice. Peptides 2011; 32: 1317.

[13] Yuan R, Clynes R, Oh J, Ravetch JV, Scharff MD. Antibodymediated modulation of Cryptococcus neoformans infection is dependent on distinct $\mathrm{Fc}$ receptor functions and $\mathrm{IgG}$ subclasses. J Exp Med 1998; 187: 641-8.

[14] Inoue Y, Matsuwaki Y, Shin SH, Ponikau JU, Kita H. Nonpathogenic, environmental fungi induce activation and degranulation of human eosinophils. J Immunol 2005; 175: 543947.

[15] el-Dahr JM, Fink R, Selden R, Arruda LK, Platts-Mills TA, Heymann PW. Development of immune responses to Aspergillus at an early age in children with cystic fibrosis. Am J Respir Crit Care Med 1994; 150(6 Pt 1): 1513-8.
[16] Krasnick J, Greenberger PA, Roberts M, Patterson R. Allergic bronchopulmonary aspergillosis: serologic update for 1995. J Clin Lab Immunol 1995; 46: 137-42.

[17] Hohl TM, Van Epps HL, Rivera A, et al. Aspergillus fumigatus triggers inflammatory responses by stage-specific beta-glucan display. PLoS Pathog 2005; 1(3): e30.

[18] Lund FE, Hollifield M, Schuer K, Lines JL, Randall TD, Garvy BA. B cells are required for generation of protective effector and memory CD4 cells in response to Pneumocystis lung infection. J Immunol 2006; 176: 6147-54.

[19] Hoselton SA, Samarasinghe AE, Seydel JM, Schuh JM. An inhalation model of airway allergic response to inhalation of environmental Aspergillus fumigatus conidia in sensitized BALB/c mice. Med Mycol 2010; 48: 1056-65.

[20] Samarasinghe AE, Hoselton SA, Schuh JM. A comparison between intratracheal and inhalation delivery of Aspergillus fumigatus conidia in the development of fungal allergic asthma in C57BL/6 mice. Fungal Biol 2011; 115: 21-9.

[21] Oliveira FL, Aguiar AM, Borojevic R, El-Cheikh MC. IgE expression on the surface of B1 and B2 lymphocytes in experimental murine schistosomiasis. Braz J Med Biol Res 2005; 38: $1033-42$.

[22] Wang H, Clarke SH. Evidence for a ligand-mediated positive selection signal in differentiation to a mature B cell. J Immunol 2003; 171: 6381-8.

[23] Martin F, Kearney JF. B1 cells: similarities and differences with other B cell subsets. Curr Opin Immunol 2001; 13: 195-201.

[24] Ibrahim-Granet O, Philippe B, Boleti H, et al. Phagocytosis and intracellular fate of Aspergillus fumigatus conidia in alveolar macrophages. Infect Immun 2003; 71: 891-903.

[25] Cenci E, Mencacci A, Fe d'Ostiani C, et al. Cytokine- and T helperdependent lung mucosal immunity in mice with invasive pulmonary aspergillosis. J Infect Dis 1998; 178: 1750-60.

[26] Polonelli L, Casadevall A, Han Y, et al. The efficacy of acquired humoral and cellular immunity in the prevention and therapy of experimental fungal infections. Med Mycol 2000; 38(Suppl 1): 281-92.

[27] Yoshizawa $\mathrm{Y}$, Ohtani $\mathrm{Y}$, Inoue T, et al. Immune responsiveness to inhaled antigens: local antibody production in the respiratory tract in health and lung diseases. Clin Exp Immunol 1995; 100: 395-400.

[28] Walker CA, Fitzharris P, Longbottom JL, Taylor AJ. Lymphocyte sensitization to Aspergillus fumigatus in allergic bronchopulmonary aspergillosis. Clin Exp Immunol 1989; 76: 34-40.

[29] Ghosh S, Hoselton SA, Schuh JM. Mu-chain-deficient mice possess B-1 cells and produce $\operatorname{IgG}$ and $\operatorname{IgE}$, but not IgA, following systemic sensitization and inhalational challenge in a fungal asthma model. J Immunol 2012; 189: 1322-9.

[30] Lindell DM, Berlin AA, Schaller MA, Lukacs NW. B cell antigen presentation promotes Th2 responses and immunopathology during chronic allergic lung disease. PLoS One 2008; 3: e3129.

[31] Macpherson AJ, McCoy KD, Johansen FE, Brandtzaeg P. The immune geography of IgA induction and function. Mucosal Immunol 2008; 1: 11-22.

[32] Blanco JL, Garcia ME. Immune response to fungal infections. Vet Immunol Immunopathol 2008; 125: 47-70.

[33] Rapaka RR, Kolls JK. Pathogenesis of allergic bronchopulmonary aspergillosis in cystic fibrosis: current understanding and future directions. Med Mycol 2009; 47 (Suppl 1): S331-7.

[34] Mukherjee S, Lee SC, Casadevall A. Antibodies to Cryptococcus neoformans glucuronoxylomannan enhance antifungal activity of murine macrophages. Infect Immun 1995; 63: 573-9.

[35] Snow RE, Djukanovic R, Stevenson FK. Analysis of immunoglobulin $\mathrm{E} \mathrm{VH}$ transcripts in a bronchial biopsy of an asthmatic patient confirms bias towards VH5, and indicates local clonal expansion, somatic mutation and isotype switch events. Immunology 1999; 98: 646-51.

[36] Blease K, Jakubzick C, Westwick J, Lukacs N, Kunkel SL, Hogaboam CM. Therapeutic effect of IL-13 immunoneutralization during chronic experimental fungal asthma. J Immunol 2001; 166: 5219-24.

[37] Grunig G, Warnock M, Wakil AE, et al. Requirement for IL-13 independently of IL-4 in experimental asthma. Science 1998; 282 2261-3.

[38] Kuperman DA, Huang X, Koth LL, et al. Direct effects of interleukin-13 on epithelial cells cause airway hyperreactivity and mucus overproduction in asthma. Nat Med 2002; 8: 885-9. 
[39] Larche M, Robinson DS, Kay AB. The role of T lymphocytes in the pathogenesis of asthma. J Allergy Clin Immunol 2003; 111: 450-63; quiz 64

[40] Korsgren M, Erjefalt JS, Korsgren O, Sundler F, Persson CG. Allergic eosinophil-rich inflammation develops in lungs and airways of B cell-deficient mice. J Exp Med 1997; 185: 885-92.

[41] Hamelmann E, Takeda K, Schwarze J, Vella AT, Irvin CG, Gelfand EW. Development of eosinophilic airway inflammation and airway hyperresponsiveness requires interleukin-5 but not immunoglobulin E or B lymphocytes. Am J Respir Cell Mol Biol 1999; $21: 480-9$

[42] Oshiba A, Hamelmann E, Takeda K, et al. Passive transfer of immediate hypersensitivity and airway hyperresponsiveness by allergen-specific immunoglobulin (Ig) E and IgG1 in mice. J Clin Invest 1996; 97: 1398-408.

(c) Ghosh et al.; Licensee Bentham Open.

This is an open access article licensed under the terms of the Creative Commons Attribution Non-Commercial License (http://creativecommons.org/licenses/by-nc/ $3.0 /$ ) which permits unrestricted, non-commercial use, distribution and reproduction in any medium, provided the work is properly cited. 